\title{
Innovative Construction of Quality Management System for Chinese-foreign Cooperative Program
}

\author{
Haiying $\mathrm{Ma}^{1, \mathrm{a}^{*}}$ and Rangjia Cai ${ }^{2, \mathrm{~b}}$ \\ ${ }^{1,2}$ School of Economics, Northwest Minzu University, Lanzhou (730124), P.R.China \\ alxmahaiying8888@163.com, b522766108 @qq.com
}

\begin{abstract}
Keywords: Innovation model; Chinese-foreign Cooperative program; Quality control
\end{abstract}
\begin{abstract}
The Chinese-foreign cooperative program is applied characteristic development of universities as well as the important way to promote the teaching level. On the basis of analysis of the applied university cooperation innovation mode and its advantages of the project, this article analyses the mode of Chinese-foreign cooperative program and the problems existing in the mode of running quality management, and connecting with the teaching quality management experience abroad and domestic. The concrete practice of the cooperative program of built is suitable for the quality management system of Chinese-foreign cooperative program.
\end{abstract}

\section{Introduction}

Internationalization is an important characteristic and inevitable trend of the development of education in the world. The national medium and long-term education reform and development of cross gauge outline (2010-2020), pointed out that encouraging schools at various levels and of various kinds of international exchanges and cooperation, do a good job in a number of demonstration Chinese-foreign cooperation schools and a batch of Chinese-foreign cooperative program project. Chinese-foreign cooperative programs are conducive to the introduction of high-quality education resources abroad, which is conducive to the cultivation of international innovative talents. At present, Chinese-foreign cooperative programs show rapid development momentum and social influence is expanding of March 2015. Nearly 600 colleges and universities across the country had been held 2058 Chinese-foreign cooperative program project and institutions with the graduate's more than 1.5 million students. Among them, the undergraduate for the Chinese-foreign cooperative program project 826 , nearly a year 70 new items.

Because of the Chinese and foreign education motivation, training mode, curriculum setting, management system, teaching mode, cultural background, are big differences in the way of communication, the Chinese-foreign cooperative program still exist the introduction of high-quality resources level needs to improve.

The teaching behavior needs to be standardized, the discipline structure needs further optimization, and the teaching quality safeguard measure is not perfect and so on. Delve into accounts for half of China's higher education, therefore, the quality problems in the teaching of applied university Chinese-foreign cooperative program, to the sustainable development of the applied university and promote our country's higher education internationalization has important practical significance.

\section{Innovative Model of Chinese-foreign Cooperative Programs}

Sino-foreign cooperative program pattern mainly divided into three kinds, the first is integrated, namely the " $4+0$ " model, to complete the project all in China to study, comprehensive introduction of foreign teaching program, course module, teaching plan, evaluation approach, foreign teachers or teachers from both sides. This model has the characteristics of low cost, high gold content, and international teaching methods of studying abroad in China, which is adopted by most of the cooperative institutions. The " 2 +2 " mode: the project with the method of the Chinese and foreign cooperation both sides to divide, 
before 2 years of learning at home, give priority to with Chinese teachers, teaching methods, to enable students to understand abroad will also hire some foreign teachers shoulder some of the course.

The students will study abroad in the year of the year, and the two sides will take the form of classes, recognize the credits, and complete the teaching plan of the degree course. The two sides will be awarded the diploma and diploma, similar to patterns including " $3+1$ "and " $3+2$ ". The third kind is loose, this is the form of a single degree, namely hiring foreign teachers to teach at home, we are sending teachers or students to study in the foreign study or short, this kind of mode is mainly to increase international teaching link, is the primary stage of Chinese-foreign cooperative program.

In recent years, the pattern of Chinese-foreign cooperative program presented the trend of diversification, such as the northwest university for nationalities Sino-USA cooperation in international economic and trade professional comprehensive integrated and grafting types to adopt the hybrid model of " $2.5+0.5+1$ ", the domestic study of 2.5 years, 0.5 years, studying abroad continue to learn one year after the return, among them, in the domestic each semester to open the teaching of specialized courses, the teaching contents, teaching methods and examination patterns are carried out in accordance with the United States provided by the module description lecture, students complete their studies by the regulation, the thesis through the china-us joint, passed, awarded the diploma and bachelor's degree certificate. Advantage of the model include: lower cost and shorter length of schooling, the advantage of better able to introduce and draw lessons from the foreign teaching resources, conducive to the Chinese-foreign cooperation in professional management and practice and employment of students, promote all-round cooperation from both sides of the Chinese-foreign cooperative, helped the foreign Chinese-foreign professional identity, but the innovation model is faced with some new problems in the process of implementation.

\section{Problems Existing in the Quality Management}

The Complexity of Teaching Management and Higher Requirements. One is the conflict of Chinese and foreign teaching management system to the influence of cooperative program, this is similar to integrated model, such as credits and period of conversion, the arrangement of the teaching process, the appraisal way and content requirements, etc.; Second, the innovation mode of the foreign module rebuilt and the complexity of the make-up exam, such as courses in the United States can only be arranged by within the territory of China in remote make-up examination, need to communicate with us again and again, to determine the suitable time and way of make-up examination; 3 it is to undertake a large number of foreign affairs and auxiliary work, both the foreign professor centralism teaching arrangements, reception, translation and teaching assistant work, also included students go abroad formalities, remote teaching equipment debugging work, and the management of the overseas students.

The Difficulty in the Process of Cultivation Influences. In the innovation mode, students will gradually differentiate into two different groups: only the Chinese diploma and the students applying for the diploma. Quantity for various reasons the two group members presents the dynamic change tendency, such as the foreign examination not through or poor foreign language level, such as given to turn professional restrictions and the lack of teachers and management personnel, the diversity of the innovation mode is also difficult to adopt curriculum and student management, apply the diploma only group must complete the same teaching plan, which will inevitably bring the evaluation system of injustice, in this mode, students pay more attention to apply for the diploma of average, this brings the injustice of the teaching process.

The Difficulties in Teaching and Teaching Supervision. As most learning is done in China, it is necessary to employ a large number of foreign languages and professional teachers, foreign teachers of scarcity, especially in small language cannot be used in teacher employment competition mechanism, and there are language barriers, and the concept of China for foreign teachers teaching supervision work is obvious; In addition, when there is a certain foreign when phenomenon of failed to pass the course, it is difficult to control in advance and process regulation, this raises the difficulty for professional follow-up management. In addition, foreign teachers are short, lack of long-term planning and enough sense of responsibility of teaching. 
The Strict Requirement of Teaching Proportion of Double Certificates. Although the general admission score is lower than that of ordinary majors, Chinese and foreign cooperation majors still have difficulty in recruiting all the ideal students. Domestic colleges and universities adopt the policy of easy entrance and strict exit, while the foreign higher education adopts the policy of strict entrance and easy exit.

Differences in educational philosophy influenced to get double the proportion of students, such as the subject of administration English level of the demand is higher, and the China international economic and trade of students have no English foundation, combined with foreign teachers in English teaching lack of necessary examination training, caused many students find it difficult to get us through to my English exams diploma phenomenon.

Language Learning, Digestive Problems and the Professional Knowledge. Innovation mode of students opened more foreign language learning module, compared with the same ordinary professional educational system, Chinese-foreign cooperation in the professional module is relatively small, because students spend a lot of time to prepare for the foreign language level examination, students spend in the professional study don't have enough time and energy, plus the foreign centralism teaching, caused a lot of students struggle with, hard to digest, if it is minor languages such as French professional cooperation, language learning and digestive problems will become more prominent, more than a variety of reasons caused the Chinese-foreign cooperative professional students professional knowledge is not solid, professional ability raise.

\section{Strategies for Managing the Quality Management}

Based on the experience of foreign countries, combined with the practice of Chinese-foreign cooperative program supervision and application university construction, the target system is proposed.

We use five aspects, the process system, monitoring system, feedback system and risk prevention system in, take the northwest university for nationalities international economy and trade as example to explore innovative strategies to respond to the Chinese-foreign cooperative program under the mode of quality management.

Target System. In this paper, the principle of running schools, the characteristics of running schools and the motivation of running schools are put forward, and the target system of Chinese-foreign cooperative program is put forward, which is scientific and reasonable, mutual support and mutual recognition. Logistics project team of China and the United States and around the enterprise logistics ability request, on the carrier of enterprise project, build the ability of professional talents cultivation, modularize module system, the experiment center and training practice base outside school, "double division" structure of professional teaching team, the professional standards and management system with the module, Research and research and social services construction target system.

Process System. Many current university cooperative programs in each teaching link general lack of fine daily management, the logistics project puts forward applied Chinese-foreign cooperative program on the basis of the whole process of quality management system of quality assurance process. In the education input, on the one hand, through strengthening professional construction, improving the professional social impact, and strengthening the recruitment publicity, and carrying out the English teaching of the provincial demonstration high school

To encourage more qualified candidates to apply for this major, overseas recruitment professional professor, on the other hand, in the domestic teaching for a long time or to accept the Dr To visiting our school or work for a long time, to establish a stable us professional teachers, to avoid the disadvantages of centralism teaching, reduce the difficulty of the foreign quality supervision. In the course of education, this major is under the guidance of the USA certification experts.

Comprehensive combing professional module of teaching content, teaching arrangement, evaluation method, etc., to further the knowledge of Chinese and foreign professional module connecting link of system integration and organize the team to the United States foreign translation and study of teaching content help every students better to absorb and digest professional knowledge, at the same time, the Chinese professional teachers to actively participate in modular teaching material writing, improve the 
teaching effect. In education on the output of the enterprise network management model and the theory of customer relationship management, formulates the enterprise network construction and development planning, strengthen the policy support and capital investment, build a different subject, different levels, including at home and abroad and cover the logistics enterprise network, provides the guarantee for the professional practice teaching and the practice and employment.

Monitoring System. From the perspective of practice, the internal quality monitoring of Chinese-foreign cooperative programs is more important. The logistics system analysis, the ministry of education and the external quality monitoring system, such as the United States DAAD, on the basis of the combination of applied university training goal and professional characteristics, in view of the existing assessment system passive assessment, regulatory system shall not apply to the in-depth reform and the problem of cycle is too long,

Establish a quality control system for Chinese-foreign cooperative programs for applied universities.

Feedback System. The system is connected with the above three systems, and plays a role of adjustment and supervision in the teaching quality assurance system. By analyzing the way, time, channel, content and process of feedback, the feedback system of students, parents, teachers and society is constructed to continuously improve and improve the teaching quality. For this professional special rules, communicate with related department in advance communication, asking the school leader when necessary, timely solve may face such problems as teaching system, teaching arrangement, gain the understanding and support of the relevant departments, at the same time, with the United States, head of the teaching management of regular exchange, timely communications project operation are faced with the problem and solving, safeguard China international economic and trade professional daily operation can be smoothly carried out.

Risk Prevention System. Applied Sino-foreign cooperative undergraduate project faces the risk of more complex and diverse, the implementation of a weekly meeting system, students daily attendance system, four years of professional instructors construct with the US regular video system, such as weekly report in the current working and planning, daily check and supervise the students English learning and professional learning situation, the Chinese team every two weeks with the us team video communication, more accurate and real-time information exchange, prevent the occurrence of emergency misunderstanding and miscalculation.

\section{Conclusions}

Chinese-foreign cooperative program is an important content of higher education in China, after more than 30 years of development, Chinese-foreign cooperative program in China has experienced a bud, the exploration and development, currently at the maturity stage, appeared a variety of school-running mode, this paper explores the innovation. Mode under the new conflicts and challenges facing the Chinese-foreign cooperative program puts forward the innovation of Chinese-foreign cooperative program under the mode of quality management system construction and the countermeasures and Suggestions, to promote our country's higher education internationalization provides a useful reference.

\section{Acknowledgements}

This work was supported by the Pilot project of comprehensive professional reform of International Economics and Trade (Joint Program, USU and NWUN) (Grant No:2017XJZYZHGGSD-01) and by Research project on education and teaching reform (Grant No:2017XJJG-12) of the Northwest Minzu University.

\section{References}

[1] Zhang Fan, Research on the analysis of the current situation of Chinese-foreign cooperative programs in China and the countermeasure of quality assurance, Chinese Adult Education, 4 (2012)60-71. 
[2] Cheng Mo, Why is the China-foreign cooperation school stopped? China National Education, 3(2011) 12-20.

[3] Wang Jiefang, Analysis of contradictory factors in the quality management of Chinese-foreign cooperative programs under the integrated teaching model, Education teaching BBS, 2012, (29) : 79-80.

[4] Zhao Yanzhi, Meng Tao, Research on the quality assurance system of Chinese-foreign cooperative programs, Education and Teaching 10(2015) 16-23.

[5] Sun Zewen, Internal monitoring and system construction of Chinese-foreign cooperative program teaching quality, Education and Teaching Research, 1 (2011) 64-72.

[6] Lin Yongbin, Research on the mode of running a school for higher education in China, Education and Teaching Forum, 2(2015)12-19.

[7] Linhui Lin, Specification, healthy, orderly, Professor Lin about Chinese-foreign do learn, People's Daily, 2(2010)8-14. 